\title{
TRANSFORMASI CERITA WAYANG DALAM NOVEL AMBA DAN PULANG
}

\author{
Burhan Nurgiyantoro \\ FBS Universitas Negeri Yogyakarta \\ email: burhan@uny.ac.id
}

\begin{abstract}
Abstrak
Penelitian bertujuan mendeskripsikan bentuk-bentuk transformasi unsur cerita wayang dalam novel Amba dan Pulang. Subjek penelitian adalah novel Amba karya Laksmi Pamuntjak dan Pulang karya Leila S. Chudori. Data dikumpulkan lewat kajian pustaka dan analisis wacana; kedua novel sebagai sumber data primer dan buku-buku cerita wayang sebagai sumber data sekunder. Data dianalisis secara deskriptif kualitatif. Hasil penelitian sebagai berikut. Transformasi cerita wayang secara intensif ditemukan pada aspek penokohan dan alur. Transformasi penokohan mencakup tiga bentuk, yaitu hipogram nama dan karakter, karakter tanpa nama, dan nama tanpa karakter. Transformasi alur mencakup dua bentuk, yaitu kisah cinta segitiga dan hubungan kekeluargaan. Alur kisah cinta segitiga dalam novel Amba melibatkan tokoh Amba, Salwa, dan Bhisma yang berhipogram pada cerita wayang dengan tokoh yang sama. Alur kisah cinta segitiga novel Pulang melibatkan tokoh Dimas, Surti, dan Hananto yang secara metaforis berhipogram pada kisah cinta Bima, Drupadi, dan Arjuna. Kerinduan pada tanah air Dimas sebagai eksil berhipogram secara metaforis kepada Ekalaya.
\end{abstract}

Kata kunci: tranformasi, cerita wayang, novel Indonesia, hipogram

\section{THE TRANSFORMATION OF SHADOW PUPPET STORIES IN NOVEL AMBA AND PULANG}

\begin{abstract}
This study aims to describe forms of the transformation of shadow puppet story elements in Amba and Pulang. The research subjects were Laksmi Pamuntjak's novel Ambaand Leila S. Chudori's Pulang. The data were collected through the study of literature and discourse analysis; the two novels were the primary data sources and shadow puppet story books were the secondary data sources. The data were analyzed using the qualitative descriptive technique. The findings are as follows. The intensive transformation of shadow puppet stories is found in the aspects of the characterization and plot. The characterization transformation has three forms, namely name and character hypograms, characters without names, and names without characters. The plot transformation groove consists of two forms, namely the love triangle and family relationships. The love triangle plot in Ambainvolves the characters Amba, Salwa, and Bhisma that have hypograms in the shadow puppet story referring to the same characters. The love triangle plot in Pulang involves the characters Dimas, Surti, and Hananto that metaphorically have hypograms referring to the love story of Bima, Drupadi and Arjuna. As an exile, Dimas longs for his country, which metaphorically has a hypogram referring to Ekalaya.
\end{abstract}

Keywords: transformation, shadow puppet stories, Indonesian novels, hypogram 


\section{PENDAHULUAN}

Hadir ke hadapan kita pembaca dua buah novel Indonesia modern karya dua orang penulis perempuan ternama yang cukup menarik, menghenyak, memukau, dan bahkan masih terasa membekas di hati dan pikir beber apa minggu setelah membacanya. Pengarang dan novel yang dimaksud adalah Laksmi Pamuntjak dengan Amba (2012) dan Leila S. Chudori dengan Pulang (2012). Para pengarang perempuan Indonesia kini terlihat berada di pusaran penting pada perkembangan sastra Indonesia. Selain Laksmi Pamuntjak dan Leila S. Chudori, untuk menyebut beberapa nama yang lain yang juga terkenal adalah Ayu Utami, Dee Lestari, Djenar Mahesa Ayu, Fira Basuki, dan lainlain. Novel $A m b a$ juga telah terbit bahasa Inggris dengan judul The Question of Red, banyak mendapat sambutan pembaca karena memang menarik. Demikian pula halnya dengan novel Pulang yang tidak kalah menarik.

Hal yang menarik perhatian pembaca begitu selesai membaca kedua novel itu pada umumnya adalah terkait dengan masalah politik, khususnya yang terkait dengan peristiwa pemberontakan PKI dengan G30S-nya dan nasib mantan para tahanan politik. Apalagi novel keduanya muncul dalam waktu yang relatif bersamaan, yaitu sama-sama terbit pertama tahun 2012. Lebih dari itu, walau dengan cerita dan stile yang berbeda, kedua novel sama-sama mengambil pokok permasalahan terkait politik tentang pemberontakan G30S/PKI dan dampak bagi para tahanan politik dan sesudahnya (mantan tahanan politik, tapol), khususnya bagi orang-orang tertuduh tanpa pengadilan yang bahkan sebenarnya tidak tahumenahu dengan dunia politik. Jika novel $A m b a$ mengangkat latar tahanan politik PKI di Pulau Buru, pulau yang secara khusus untuk memenjarakan mereka, novel Pulang berlatar di luar negeri terutama di Paris, Prancis.
Pada awal tahun 80-an terbit tetralogi novel Pamodya Ananta Toer yang diberi sebutan Novel Pulau Buru. Tetapi, novel Pramodya sama sekali tidak menyinggung kehidupan tahanan politik di pulau itu dan jusru pada novel $A m b a$ inilah hal tersebut sedikit dikuakkan. Novel Amba seolah-olah mengingatkan kembali perihal Pulau Buru yang "angker" itu kepada masyarakat dewasa ini, sedang Pulang lebih mengingatkan perlakuan dan nasib para eksil korban politik yang sama yang mendambakan kebebasan. Misalnya, salah satu komentar pembaca (Amarzan Loebis) yang dimuat di halaman depan kedua novel itu. Komentar untuk novel Amba: "Novel ini membayurkan yang khayali dan yang bayan dengan cara yang sangat indah dan cerdas. Amba juga merupakan bagian dari "perjuangan melawan lupa" akan luka sejarah bangsa ini yang tak kunjung pulih". Komentar untuk novel Pulang: "Tanpa pretensi, novel Pulang masuk ke dalam ikhtiar merawat ingatan tentang salah satu "gempa politik" terbesar di negeri ini. Karya luar biasa, asyik tapi tetap sederhana.

Selain terkait dengan masalah politik, pembaca yang mengerti cerita wayang, begitu membaca novel yang berjudul Amba itu pasti langsung teringat salah satu nama tokoh wayang: Dewi Amba. Dewi Amba adalah tokoh perempuan wayang yang hidup semasa Bhisma muda (: Dewabrata), jadi sebelum era Pandawa, namun cukup berperan dalam Perang Besar Bharatayuda yang dimenangkan oleh Pandawa. Artinya, novel terkait dengan cerita wayang. Artinya, tidak hanya aspek politik yang menarik dan perlu mendapat perhatian. Keterkaitan dengan cerita wayang itu terasa lebih tegas setelah membaca novel yang ternyata mengangkat tokoh yang juga merujuk nama-nama tokoh-tokoh wayang yang lain: Bhisma dan Salwa, bahkan juga ada Ambika, Ambalika, Srikandi walau ketiganya bukan tokoh penting. Bahkan, pada subsubjudul buku dan bab hampir semuanya 
diberi nama tokoh wayang. Selain itu, ada kutipan dari buku klasik (parwa), yaituUdayoga Parva, Aswa medha Parva, dan Bhisma Parva tentang cerita wayang yang telah diindonesiakan. Pada intinya aroma cerita wayang terlihat cukup kental.

Agak berbeda halnya untuk novel Pulang yang dari sisi judul tidak berbau cerita wayang. Namun, setelah membacanya, bahkan belum menyelesaikan setengah buku, aroma wayang sudah terasa kental. Dalam hal tertentu, bahkan terasa lebih intesif daripada yang tersaji dalam Amba. Misalnya, ia menghadirkan secara khusus cerita yang sengaja dicetak miring; jadi semacam catatan tambahan untuk mempertegas alur cerita novel. Novel Pulang juga menghadirkan namanama tokoh fiksi yang merujuk nama tokoh-tokoh wayang seperti Surti(-kanti) Annandari, Rukmini, Narayana, Ekalaya, Bima, Andini, dan Rama. Namun, tokoh utama cerita, Dimas Surya, justru tidak berasal dari nama tokoh wayang. Sama halnya dengan novel $A m b a$, ada beberapa subjudul bab juga ada yang diberi nama dengan nama tokoh wayang. Oleh karena itu, perlu ada sambutan oleh pembaca terhadap aroma atau transformasi cerita wayang pada kedua novel tersebut.

Jejak budaya tempat seseorang dilahirkan dan atau dibesarkan lazimnya cukup membekas dan sulit dilupakan. Hal yang demikian juga terjadi pada para pengarang. Mereka boleh melanglang jagad dan tinggal di manapun, namun latar belakang budaya yang telah membesarkannya itu tetap saja sering dirindukan. Hal itu adalah sebuah kerinduan arkitipal dan memiliki peran yang tidak kecil terhadap perkembangan kebudayaan (baca: kesastraan) Indonesia (Darma, 1995:171). Keadaan itu juga didukung fakta bahwa tiak sedikit pengarang Indonesia dewasa ini yang merujuk dan mengangkat berbagai latar belakang budaya masa lalunyasebut sebagai budaya tradisional-yang telah membentuknya itu. Laksmi Pa- muncak dan Leila S. Chudori hanyalah dua contoh pengarang yang memiliki kerinduan arkitipal itu dan kemudian mengekspresikan kerinduannya terhadap pada karya fiksinya.

Namun, untuk kasus kedua pengarang perempuan ini cukup menarik. Dilihat dari sisi biografi, keduanya tidak lahir dan dibesarkan dalam latar budaya wayang yang kental seperti di Jawa (Tengah dan Yogyakarta), namun terlihat mereka memahami dengan baik latar budaya cerita wayang. Hanya saja keduanya tidak melulu merujuk cerita wayang versi Jawa, melainkan lebih ke versi India. Hal itu mungkin karena mereka lebih menikmati cerita wayang lewat sarana tulisan (buku) tentang wayang, khususnya yang versi India, daripada yang versi Jawa atau lewat pertunjukan wayang (kulit atau orang) seperti halnya orang yang dibesarkan di Jawa.

Cerita wayang adalah salah satu warisan budaya tradisional yang amat populer hingga kini. Cerita wayang dewasa ini tidak hanya miliki masyarakat etnis tertentu seperti Jawa dan Bali, tetapi telah menjadi miliki bangsa Indonesia dan bahkan menjadi kebanggaan nasional. Hal itu disebabkan eksistensi budaya wayang telah diakui di level internasional, khususnya oleh UNESCO, sebuah lembaga di bawah PBB yang menangani masalah pendidikan, ilmu pengetahuan, dan kebudayaan. Pada tahun 2003, UNESCO telah menetapkan budaya wayang Indonesia sebagai karya agung dunia, sebagai Masterpiece of Oral and Intangible Heritage of Humanity (Wibisono, 2009; Sudjarwo dkk, 2010; Kasnowihardjo, 2012). Oleh karena itu, wajar jika cerita wayang banyak dijadikan sumber rujukan bagi penulisan karya sastra di Indonesia modern.

Sebelumnya, UNESCO telah menyusun peraturan mengenai Masterpiece of Oral and Intangible Heritage of Humanity.Tujuan peraturan itu antara lain adalah untuk meningkatkan kesadaran masyarakat 
dunia terhadap warisan budaya tak benda, mengevaluasi dan mendaftar situs dan warisan budaya tak benda, dan membangkitkan semangat pemerintah negara agar mengambil tindakan-tindakan hukum dan administrasi untuk melestarikan warisan budaya tak benda (Wibisono, 2009). Setiap negara yang memiliki karya-karya tradisional sebagaimana dimaksudkan di atas boleh mengajukan permohonan untuk diumumkan sebagai karya agung dunia. Indonesia memiliki warisan cerita tradisional wayang yang dapat diajukan untuk memperoleh penghargaan tersebut.

Terhadap pengangkatan cerita ke dalam karya sastra Indonesia juga telah banyak menarik perhatian penelitian untuk menelaahnya, bahkan juga oleh peneliti berkebangsan asing. Untuk menyebut sebagian saja, hal itu misalnya dilakukan oleh Figueras-Lucero (1997) yang meneliti aspek wayang dalam novel Perburuan karya Pramodya; tesis Sumukti (2006) yang meneliti tokoh Semar dalam budaya wayang Jawa; Basuki (2006) yang meneliti peran Panakawan dalam kekuasaan pemerintahan Orde Baru; Kusmarwati (2010) yang meneliti wayang sebagai refleksi politik dalam novel Mantra Pejinak Ular Karya Kuntowijoyo; Downes (2012) yang meneliti aspek wayang dalam novelnovel Indonesia modern tiga pengarang Indonesia; Mustikasari dkk (2012) yang meneliti aspek wayang dalam novel $D i$ Batas Angin karya Yanusa Nugroho; dan disertasi Varela (2014) yang meneliti inovasi cerita wayang Jawa kontemporer.

Perujukan cerita wayang dalam fiksi modern menunjukkan adanya tanggapan pengarang terhadap cerita itu. Terhadap cerita wayang pengarang adalah pembaca yang memberikan tanggapan. Tanggapan tersebut bersifat aktif-kreatif lewat kekuatan imajinasi dan kemudian dimanifestasikan ke dalam tulisan yang berwujud novel. Dengan demikian, teori yang dipergunakan dalam penelitian ini adalah teori resepsi dan intertekstual. Iser (Habib, 2005:724) mengemukakan bahwa dalam hal resepsi tersebut terdapat dua pola, yaitu pola "artistik" itu dikreasikan oleh pengarang dan pola estetik yang secara nyata dilakukan oleh pembaca. Di pihak lain, intertekstual akan terjadi jika sebuah teks kesastraan merujuk, mengambil, meminjam, mengutip, mengadaptasi, mereaktualisasi, atau menransformasikan sesuatu dari sumber atau teks lain kedalam teks tersebut (Lesmater, 2012). Perujukan pada teks-teks yang telah ada sebelumnya dikenal dengan sebutan hipogram (Riffaterre, 1980), baik bersifat meneruskan maupun menolak konvensi.

Penelitian ini bertujuan untuk mendeskripsikan bentuk-bentuk transformasi berbagai unsur wayang dalam novel Amba dan Pulang.

\section{METODE}

Penelitian menggunakan pendekatan tekstual-kualitatif. Baik sumber data maupun data hasil deskripsi semua berupa lambang verbal. Sumber data utama adalah novel Amba karya Laksmi Pamuntjak yang terbit pertama 2012 (cetakan kelima Juni 2015) yang juga terbit dalam bahasa Inggris dengan judul The Question of Red (telah cetak ulang beberapa kali dan menjadi national bestseller); dan novel Pulang karya Leila Salikha Chudori yang terbit pertama juga tahun 2012 (cetakan ketujuh Februari 2016). Fokus penelitian adalah bentuk-bentuk transformasi berbagai unsur wayang dalam kedua novel itu. Selain itu, penelitian didukung oleh berbagai sumber buku tentang cerita wayang seperti: Rupa \& KarakterWayangPurwa (Heru S. Sudjarwo, Sumari, dan UndungWiyono, 2010), Ensiklopedi Wayang (Djoko Dwiyanto, Sukatmi Susantika, Wiwien Widyawati, 2010), Silsilah Wayang PurwaMawa Carita, jilid I3/4VII (S. Padmosoekotjo, 1992), Mahabharata (C. Rajagopalachari, 2008), dan Mahabrata (P. Lal, 1992). 
Data diperoleh lewat kajian pustaka denganmemanfaatkan teknik analisis wacana khususnya yang berupa instrumen pengetahuan tentang dunia 'knowledge of the world' (Brown \& Yule, 1983). Data hasil kajian tersebut dianalisis dengan teknik deskriptif kualitatif melalui langkah pembandingan antardata, kategorisasi, penyajian data, dan pembuatan inferensi. Keabsahan data dilakukan lewat pembacaan berulang (validitas semantis), rujukan ke buku sumber (validitas referensial), dan diskusi dengan sejawat (reliabilitas interrater).

\section{HASIL DAN PEMBAHASAN Hasil}

Novel Amba. Secara garis besar novel ini berkisah tentang cinta segi tiga antara Amba, Salwa, dan Bhisma. Amba telah ditunangkan dengan Salwa yang seorang dosen oleh orang tuanya, Sudarminto. Namun, Amba justru mencintai Bhisma, seorang dokter yang dijumpainya lebih kemudian. Amba segera memutuskan cinta Salwa kepadanya. Kisah romantisme percintaan Amba dan Bhisma hanya berlangsung singkat karena Bhisma keburu ditangkap tentara karena dituduh terkait dengan pemberontakan PKI. Padahal, Bhisma tidak berpolitik, tidak terkait dengan itu semua,dan hanya membantu menolong orang-orang yang terluka. Amba kehilangan Bhisma padahal ia sudah terlanjur hamil. Untuk menutup rasa malu, ia kawin dengan laki-laki Amerika, Adalhard, yang mencintainya. Belakangan Amba tahu Bhisma dibuang ke Pulau Buru tempat penampungan tahanan politik. Tetapi, ketika para mantan tapol itu pulang, Bhisma tidak ikut serta. Akhirnya, Amba mencarinya ke Pulau Buru, tetapi Bhisma sudah meninggal dan hanya meninggalkan surat-surat untuknya.

Transformasi Cerita wayang. Transfromasi cerita wayang ditemukan pada aspek penokohan dan alur. Pertama, transformasi penokohan mencakup model, yaitu model hipogram sebagian nama dan sebagian karakter serta hipogram nama tanpa disertai karakter. Hipogram (sebagian) nama dan karakter ditemukan pada tiga tokoh utama, yaitu Amba Kinanti, Salwa Munir, dan Bhisma Rasyad, sedang hipogram nama tanpa karakter ditemukan pada tokoh Ambika, Ambalika, dan Srikandi. Kedua, transformasi alur juga mencakup dua model, yaitu model kisah cinta tokoh dan hubungan kekeluargaan tokoh. Hipogram alur kisah cinta Amba, Salwa, dan Bhisma dari wayang adalah berupa kisah cinta segitiga. Hipogram hubungan kekeluargaan adalah bahwa Amba, Ambika, dan Ambalika merupakan kakak beradik yang bersifat meneruskan konvensi seperti halnya pada cerita wayang, serta hubungan Amba dan Srikandi yang merupakan hubungan ibu anak yang bersifat menolak konvensi cerita wayang.

Novel Pulang. Novel ini secara garis besar mengisahkan kehidupan para eksil politik yang dituduh terkait pemberontakan PKI walau sebenarnya tidak benar. Dimas Surya dan tiga kawannya yang sedang di luar negeri dicabut paspornya, menetap di Paris, dan membuka rumah makan "Tanah Air" dengan menu masakan Indonesia. Dari perkawinannya dengan Vivienne yang seorang perempuan Prancis, Dimas memunyai seorang putri, Lintang Utara. Sebagai seorang yang terbuang, eksil, Dimas sangat merindukan Indonesia. Untuk menutup rasa rindunya itu, ia mengoleksi gambar-gambar wayang dan rempah-rempah dengan bau khas yang mengingatkan Indonesia. Dimas menyamakan nasib dirinya dengan Bima dan Ekalaya. Bima mencintai Drupadi, tetapi Drupadi justru mencintai Arjuna. Ketika di Jakarta dulu, Dimas mencintai Surti, tetapi Surti justru kawin dengan Hananto. Cinta Dimas kepada Surti tidak pernah padam dan hal itu menyebabkan berakhirnya perkawinannya dengan Vivienne. Dimas juga menyamakan nasibnya de- 
Tabel 1. Model Transformasi Cerita Wayang pada Novel Amba dan Pulang

\begin{tabular}{|c|c|c|c|c|c|c|c|}
\hline \multirow[b]{2}{*}{$\begin{array}{l}\text { Judul } \\
\text { Novel }\end{array}$} & \multirow[b]{2}{*}{$\begin{array}{l}\text { Nama } \\
\text { Tokoh }\end{array}$} & \multicolumn{3}{|c|}{ Transformasi Penokohan } & \multicolumn{2}{|c|}{ Transformasi Alur } & \multirow[b]{2}{*}{ Keterangan } \\
\hline & & $\begin{array}{l}\text { Nama } \\
\text { dan } \\
\text { Karakter }\end{array}$ & $\begin{array}{l}\text { Karakter } \\
\text { tanpa } \\
\text { Nama }\end{array}$ & $\begin{array}{l}\text { Nama } \\
\text { tanpa } \\
\text { Karakter }\end{array}$ & $\begin{array}{l}\text { Alur } \\
\text { Kehidupan } \\
\text { Tokoh }\end{array}$ & $\begin{array}{l}\text { Hubungan } \\
\text { Kekeluar- } \\
\text { gaan }\end{array}$ & \\
\hline \multirow{9}{*}{$A m b a$} & Amba & $X$ & & & \multirow{9}{*}{$\begin{array}{c}\mathrm{x} \\
\text { (Cinta segi } \\
\text { tiga) }\end{array}$} & & \multirow{5}{*}{$\begin{array}{l}\text { 1) Salwa } \\
\text { mencintai } \\
\text { Amba, Amba } \\
\text { mencintai } \\
\text { Bhisma }\end{array}$} \\
\hline & Kinanti & $x$ & & & & & \\
\hline & Bhisma & $x$ & & & & & \\
\hline & Rasyad & & & & & & \\
\hline & Salwa & & & & & & \\
\hline & Munir & & & & & & \multirow{4}{*}{$\begin{array}{l}\text { 2) Ambika dan } \\
\text { Ambalika } \\
\text { adalah adik } \\
\text { Amba } \\
\text { 3) Srikandi anak } \\
\text { Amba }\end{array}$} \\
\hline & Ambika & & & $x$ & & $x$ & \\
\hline & Ambalika & & & $x$ & & & \\
\hline & Srikandi & & & $x$ & & & \\
\hline \multirow{11}{*}{ Pulang } & Dimas & & $X$ & & $x$ & & \multirow{10}{*}{$\begin{array}{l}\text { (1) Dimas } \\
\text { mencintai } \\
\text { Surti, Surti } \\
\text { mencintai } \\
\text { Hananto } \\
\text { (2) Dimas dan } \\
\text { Ekalaya } \\
\text { sama-sama } \\
\text { orang } \\
\text { terbuang }\end{array}$} \\
\hline & Surya & & & & $\begin{array}{c}\text { (Cinta segi } \\
\text { tiga) }\end{array}$ & & \\
\hline & Bima & $x$ & & & $x$ & & \\
\hline & Ekalaya & $\mathrm{x}$ & & & & & \\
\hline & Surti & & & $x$ & & & \\
\hline & Rukmini & & & $x$ & & & \\
\hline & Narayana & & & $x$ & & & \\
\hline & Bima & & & $x$ & & & \\
\hline & Andini & & & $x$ & & & \\
\hline & Rama & & & $x$ & & & \\
\hline & $\begin{array}{l}\text { Lintang } \\
\text { dan Alam }\end{array}$ & & & & & $\mathrm{x}$ & $\begin{array}{l}\text { Transformasi } \\
\text { perkawinan } \\
\text { Gatotkaca } \\
\text { dengan } \\
\text { Pergiwa }\end{array}$ \\
\hline
\end{tabular}

ngan Ekalaya yang amat mencintai Durna gurunya, tetapi ditolak. Pada akhirnya Dimas memang dapat "pulang" ke Indonesia setelah meninggal dan dimakamkan di Pemakaman Karet.

Transformasi Cerita Wayang. Transformasi cerita wayang ditemukan pada aspek penokohan dan alur. Pertama, transformasi penokohan mencakup dua model, yaitu hipogram nama dan karakter, karakter tanpa penamaan dan hipogram nama tanpa karakter. Hipogram nama dan karakter terdapat pada rujukan tokoh wayang Bima dan Ekalaya, hipogram sebagian karakter tanpa nama ditemukan pada tokoh Dimas Surya, sedang hipogram nama tanpa karakter pada tokohtokoh Surti, Rukmini, Narayana, Bima, Andini, dan Rama. Kedua, transformasi alur berupa kisah hidup tokoh hubungan kekeluargaan. Hipogram kisah hidup tokoh Dimas Surya yang berupa kisah cinta segitiga dan kerinduan tanah air yang secara metaforispada tokoh wayang Bima 
dan Ekalaya. Hubungan kekeluargaan berupa kisah cinta Lintang (anak Dimas) dengan Alam (anak Surti-Hananto) dari kisah wayang tentang perkawinan antara Gatotkaca (anak Bima) dengan Endang Pergiwa (anak Arjuna).

Model transformasi pada novel Amba dan Pulang tersebut dapat dirangkum dalam Tabel 1.

\section{Pembahasan}

Pembahasan dilakukan berdasarkan bentuk transformasi yang ditemukan, yaitu transformasi penokohan dan alur dengan kasus yang terdapat pada kedua novel.

\section{Penokohan}

Terdapat tiga bentuk transformasi penokohan dalam wujud penghipograman, yaitu hipogram (sebagian) nama dan karakter tokoh wayang sekaligus, karakter tanpa nama, dan nama tanpa karakter. Penamaan tokoh-tokoh fiksi dengan nama tokoh-tokoh wayang memperlihatkan bahwa tokoh-tokoh wayang diangkat tersebut, terlepas dari apakah tokoh tersebut difungsikan sebagai tokoh utama atau feriferal, lengkap karakter atau sekadar namanya saja, menjadi rujukan budaya. Hal itu secara jelas menunjukkan adanya aspek intertekstualitas antara keduanya (lihat Lesmater, 2012; Kusmarwanti, 2010). Budaya wayang telah terlebih dahulu eksis dan penulisan suatu karya (novel) yang lebih kemudian lazimnya berangkat dan atau tidak mungkin lepas sama sekali dari budaya yang telah ada.

Hipogram Nama dan Karakter. Nama-nama tokoh wayang sekaligus dengan karakternya dijadikan sumber rujukan dalam pengembangan tokoh novel. Hipogram bentuk ini terdapat pada novel Amba, tetapi tidak dalam Pulang. Ketiga tokoh utama novel Amba, yaitu Amba Kinanti (sebutan: Amba), Salwa Munir (sebutan: Salwa), dan Bhisma Rasyad (sebutan: Bhisma) adalah nama-nama to- koh wayang. Nama-nama tokoh wayang persisnya seperti sebutan ketiga nama tokoh novel itu, maka sebenarnya hipogram atau transformasi nama tokoh wayang itu bersifat sebagian. Namun, hal itu jelas bukan merupakan sesuatu yang hanya kebetulan saja, melainkan suatu rujukan budaya yang dilakukan secara sadar.

Hal itu akan terlihat semakin jelas ketika sebagian karakter tokoh wayang yang namanya dihipogram pada tokoh novel juga terlihat. Bahkan, kisah cinta ketiga tokoh novel juga berhipogram dari kisah ketiga tokoh wayang itu. Nama dan karakter tokoh wayang, bahkan juga kisah-kisah tertentu, telah baku, telah memiliki pakem yang baku, dan bersifat stereotip. Artinya, nama tokoh wayang dengan karakter yang disandangnya tidak berubah. Jika ada perubahan, hal itu dipastikan bukan merupakan karakter utama. Kalaupun ada penambahan, ia tidak akan mengubah karakter utama itu. Selain telah bersifat pakem, nama dan karakter tokoh wayang juga telah bersifat tipologis (Kuntowijoyo,1984:128-9). Artinya, mereka telah memiliki karakter dengan tipe tertentu yang dalam cerita wayang adalah karakter baik atau jahat. Hal demikian sudah diketahui baik penulis maupun pembaca yang memahami cerita wayang karena keduanya berangkat dari kode yang kurang lebih sama. Maka, pengangkatan tokoh-tokoh wayang apalagi mencakup juga (sebagian) karakternya akan mempersingkat penuturan dan menyebabkan komunikasi menjadi efisien.

Misalnya, tokoh-tokoh dari keluarga Pandawa bertipe karakter baik, sedang keluarga Kurawa berkarakter jahat. Pengambilan nama-nama tokoh fiksi, juga nama untuk anak-anak yang diberikan oleh orang tua di masyarakat, lazimnya dilakukan pada nama-nama tokoh-tokoh baik. Nama-nama tokoh kedua novel yang berhipogram pada tokoh-tokoh wayang di atas semuanya adalah tokoh 
yang berkarakter baik. Misalnya, Amba, Bhisma, Salwa, Srikandi, Bima, Ekalaya, Narayana, dan lain-lain. Tampaknya, jarang ditemukan pengarang yang memberi nama tokoh fiksinya dengan nama tokoh wayang yang berkarakter jahat untuk tokoh protagonis. Demikian juga tidak ada orang tua yang memberi nama anaknya dengan nama tokoh wayang jahat seperti Durna, Sengkuni, Duryudana, Rahwana, dan lain-lain. Pemberian nama kepada anak pasti mengandung harapan agar kelak anaknya mewarisi (sebagian) karakter tokoh tertentu (baca: wayang) yang dipilihnya.

Penghipograman nama tokoh Amba, Bhisma, dan Salwa, serta Dimas Surya terhadap cerita wayang semakin terlihat intensif karena juga menyangkut kisah cintanya. Kisah cinta segitiga dalam cerita wayang dihipogram menjadi kisah cinta ketiga tokoh novel itu lengkap dengan sebagian karakternya. Hal itu akan dibicarakan di bawah pada pembicaraan tentang hipogram alur.

Hipogram Karakter tanpa Nama. Tokoh novel yang berhipogram pada tokoh wayang hanya dari sisi karakter saja ditemukan hanya pada seorang tokoh, yaitu Dimas Surya (Pulang). Dimas Surya yang bekerja di Jakarta dikisahkan lahir dan dibesarkan di Solo, sebuah tempat yang masih kental akan budaya wayang. Dimas memahami dan menghayati dengan baik tokoh dan cerita wayang. Oleh karena itu, wajar-wajar saja jika budaya wayang dirasakannya amat melekat di hatinya, bahkan seolah-olah menjadi sebagian jatidirinya.

Sebagai seseorang yang memahami dan menghayati cerita wayang, Dimas Surya secara sadar merujuk dan sekaligus menyamakan dirinya dengan tokoh wayang yang diidolakannya, yaitu Bima dan Ekalaya. Dengan sadar pula ia menganggap bahwa dirinya memiliki kesamaan karakter, atau kesamaan "nasib" dengan kedua tokoh wayang itu. Kedua tokoh wayang dijadikan rujukan untuk menggambarkan eksistensi jatidirinya. Atau ketika mengalami sesuatu, Dimas Surya secara sengaja mencari rujukan (budaya) yang sesuai dengan kondisinya pada cerita wayang. Rujukan yang dilakukan adalah dengan membandingkan dirinya dengan kedua tokoh wayang tersebut secara metaforis. Sekali lagi, karena pembaca (diasumsikan) telah mengetahui pakem kedua tokoh wayang itu, penceritaan menjadi lebih efisien.

Hipogram Nama tanpa Karakter. Dibandingkan dengan hipogram karakter tanpa nama, hipogram model ini lebih mudah dikenali karena nama-nama tokoh yang diangkat dalam kedua novel itu merujuk nama-nama tokoh wayang. Nama-nama itu adalah Ambika, Ambalika, dan Srikandi (Amba), serta Surti, Rukmini, Narayana, Bima, Andini, dan Rama $(P \mathcal{H}-$ lang). Tokoh Ambika dan Ambalika, yang adalah adik Amba, hanyalah tokoh feriferal sehingga tidak banyak dikisahkan. Ambika sedikit disinggung sebagai anak yang amat cantik, lebih cantik dari Amba (versi Amba), dan terlihat mudah jatuh hati kepada laki-laki termasuk kepada Salwa. Ambalika bahkan hanya sekadar disebut saja. Srikandi, anak Amba, sedikit dikisahkan pada akhir kisah, yaitu sebagai seorang seniman lukis, fisik mirip ibunya, dan terlihat jatuh cinta kepada laki-laki kawannya ibunya.

Surti adalah kekasih pertama Dimas Surya, namun kemudian memilih menikah dengan Hananto, atasan Dimas. Rukmini adalah istri Nugroho, kawannya sesama esksil Dimas Surya, yang memilih cerai dan kawin dengan lakilaki lain. Narayana, anak blasteran ibu Jawa dan ayah Prancis, adalah kekasih Lintang Utara, anak Dimas. Andini dan Rama anak Aji Surya (adik Dimas Surya), serta Bima adalah adalah anak Nugroho. Jadi, Surti dan Rukmini adalah tokoh generasi tua, sedang Narayana dan Bima dan kawan-kawan generasi kedua setelah 
mereka. Dilihat dari sisi karakter, tidak jelas karakter apa yang menghubungkannya dengan karakter tokoh wayang yang namanya disandangnya. Rama misalnya, anak yang justru menutup-nutupi eksistensi dirinya sebagai anak saudara seorang eksil politik terlarang. Rama tidak berani bersikap jujur dan berani membela kebenaran sebagaimana halnya tokoh wayang Rama yang justru berkebalikan karakternya. Namun, bagaimanapun, paling tidak perujukan itu memperkuat rujukan tokoh yang secara nama dan karakter atau yang secara karakter saja berhipogram pada tokoh wayang.

Perujukan nama-nama tokoh dari cerita wayang baik dalam bentuk pertama, kedua, maupun ketiga menunjukkan semakin intensifnya pengaruh cerita wayang pada penulisan kedua novel itu. Hal sekaligus juga menunjukkan bahwa cerita wayang cukup kaya untuk dijadikanrujukan budaya. Perujukan kepada tokoh-tokoh yang telah memiliki nama dan karakter yang baku dan stereotip akan menyebabkan penuturan menjadi lebih efisien dan komunikatif. Paling tidak, hal itu terjadi pada pembaca yang memahami cerita wayang.

\section{Alur}

Tidak hanya aspek penokohan yang menyebabkan kedua novel itu terlihat intensif berhipogram pada cerita, tetapi terlebih karena juga didukung dan dikuatkan lewat alur. Pada kedua novel terdapat dua model alur yang mirip, yaitu samasama menampilkan kisah cinta segitiga dan adanya hubungan kekeluargaan antartokoh yang berhipogram dari cerita wayang walau dengan kisah berbeda. Namun, kisah cinta segitiga pada Amba tampak lebih konkret apalagi didukung oleh nama-nama pelaku yang sama.

Kisah Cinta Segitiga. Kisah cinta segitiga dalam novel Amba adalah sebagai berikut. Amba yang kuliah di UGM ditunangkan oleh orang tuanya dengan Salwa yang dosen UGM. Ketika Salwa bertugas di Surabaya dan Amba di Kediri, Amba bertemu dengan dr. Bhisma dan langsung saling jatuh cinta. Keduanya pun bercinta. Amba memutuskan cinta Salwa kepadanya. Karena kondisi gawat akibat pecahnya pemberontakan G30S/PKI, Amba pulang ke Yogya dan Bhisma menyusul. Bhisma ditangkap tentara dengan tuduhan terkait dengan atau simpatisan PKI, maka keduanya pun terpisah dan saling tidak mengetahui beritanya. Ternyata Amba hamil, maka ia terpaksa menerima lamaran Aldahard untuk menutup rasa malunya. Belakangan Amba menemukan jejak Bhisma yang ternyata ditahan di Pulau Buru, tetapi ketika para mantan tapol itu pulang, Bhisma tidak turut serta. Ketika suaminya telah meninggal, Amba mencari Bhisma ke Buru. Namun, Bhisma telah meninggal dan hanya meninggalkan surat-surat yang berisi kisah kehidupan para tapol kepadanya.

Cerita wayang yang dihipogram kisah cinta segitiga novel sebagai berikut. Bhisma pergi ke Kerajaan Kasipura untuk melamar tiga putri kakak beradik yang cantik jelita, yaitu Amba, Ambika, dan Ambalika, untuk kedua adiknya, Citragada dan Citrawirya. Bhisma berhasil memboyong ketiganya setelah mengalahkan para pesaingnya termasuk Raja Salwa. Ditengah jalan, Amba minta dikembalikan karena telah berjanji untuk kawin dengan kekasihnya, Salwa, dan Bhisma pun mengizinkannya. Tetapi, Salwa menolak dengan alasan harga diri dan menyuruhnya kembali ke Astina. Di Astina Citrawirya juga menolak menikahi perempuan yang mencintai laki-laki lain. Maka, Amba minta Bhisma untuk menikahinya, tetapi Bhisma menolak karena telah bersumpah hidup selibat. Karena Amba terus memaksa Bhisma, secara tidak sengaja Bhisma membunuhnya. Kelak ketika terjadi Perang Besar Bharatayuda, sukma Amba masuk ke tubuh Srikandi untuk membalas kematiannya kepada Bhisma. 
Kisah di alur novel memang tidak sama dengan di cerita wayang, tetapi tampak jelas bahwa ia berupa transformasi alur cerita wayang itu. Ada perubahan tempat, peristiwa, alasan kegagalan cinta, bahkan sampai dengan profesi para tokoh. Tetapi, ada benang merah yang secara jelas menunjukkan adanya hubungan ke-samaan: Amba sudah bertunangan dengan Salwa, kedatangan Bhisma memutuskan tali pertunangan, tetapi Amba Bhisma tidak dapat menikah. Pada cerita wayang, Amba dan Bhisma sama sekali tidak bersentuhan, apalagi bercinta sampai Amba hamil karena Bhisma pantang melanggar sumpah. Tetapi, pada novel kisah didramatisasikan dengan keduanya saling mencintai, bercinta, terpaksa terpisah karena keadaan politik, dan bahkan Amba hamil dan kelak melahirkan seorang putri, Srikandi. Walau ada perubahan (baca: transformasi) yang meliputi berbagai hal di atas, pembaca yang memahami cerita tetap saja akan dengan mudah melihat ada kesejajaran kedua kisah cinta itu.

Bahkan, di bawah subjudul novel (Buku 2: Amba, Bhisma \& Salwa, 19561965), ada prolog yang sengaja dikutip dari Kitab Udayoga Parva, CLXXVII: "Siapa yang akan kusalahakan? Diriku sendiri? Atau bapakku yang bodoh, yang mengatur siapa yang harus kupilih? Mungkin ini semua salahku! Mengapa tak kulemparkan tubuhku di depan kereta perang Bhisma yang menderu, ketika pertempuran sengit itu berlangsung menghadapi Salwa?" (Amba, 2015:83). Kutipan tersebut seolah memberi tahu pembaca bahwa kisah ketiga yang akan dikisahkan itu merujuk (berhipogram) pada cerita wayang. Hal sama juga ditemukan pada semua subjudul novel itu.

Sebagai tokoh novel, Amba juga sadar bahwa kisah cintanya mirip dengan kisah wayang. Amba tokoh novel mengetahui persis kisah Amba tokoh wayang yang berakhir tragis. Secara disadari atau tidak disadarinya, ia takut mengalami peristiwa sebagaimana yang dialami Amba tokoh wayang. Namun, ia juga percaya bahwa hidup manusia tidak akan sama dengan mitos (cerita wayang), yaitu bahwa AmbaBhisma tidak dapat bersatu. Maka, ketika Bhisma seperti telah berada dalam "genggamannya", ia berada dalam situasi jiwa berharap-harap cemas.

Mata Amba basah. Ia ingin mengucapkan sesuatu yang ia sendiri tidak tahu persisnya, separuh bahagia separuh ketakutan, ketika pelayan datang untuk mencatat pesanan mereka. Ia dengar Bhisma memesan sesuatu, barangkali nasi goreng, ia tak peduli apa. Ia masih belum percaya. Ia belum percaya bahwa semua yang diinginkannya tiba-tiba menyodorkan diri ke dalam genggamannya: bukan hanya cinta Bhisma, tapi juga janji bahwa masa depan mereka akan berbeda dengan yang ditorehkan dalam Mahabharata, bahwa hidup tak sama dengan mitos. (Amba, 2015:310-311).

Artinya, Amba tokoh novel berhipogram pada cerita wayang, tetapi (maunya) dengan menolak konvensi. Amba (maunya) menolak kegagalan cintanya kepada Bhisma. Namun, pada kenyataannya mitos cerita wayang itu terjadi pula pada Amba-Bhisma: keduanya tetap saja berpisah walau dalam keadaan, situasi, peristiwa, dan alasan yang berbeda. Artinya, walau sebagai manusia biasa Amba mau menolak mitos (konvensi), harapannya itu tidak berhasil. Kecemasan Amba tokoh novel terbukti bukannya tanpa alasan.

Kiranya perlu juga dicatat bahwa tampaknya dalam berhipogram terhadap cerita wayang tersebut, pengarang lebih mendasarkan diri pada cerita wayang versi India daripada Jawa. Nama Salwa tidak dikenal dalam cerita wayang versi Jawa, tetapi ada dalam cerita versi India, yaitu raja Kerajaan Saubala. Pada cerita wayang Jawa nama raja itu bernama Citramuka dari Kerajaan Swantipura (Ra- 
jagopalachari, 2008; Sudjarwodkk, 2010; Padmosoekotjo, 1992).

Berbeda halnya dengan novel Amba, novel Pulang menghadirkan alur kisah cinta segitiga para tokohnya, tetapi hanya secara metaforismerujuk cerita wayang. Pembandingan itu dilakukan sendiri oleh tokoh pelakunya, yaitu Dimas Surya, yang sengaja menyamakan kisanya dengan kisah dua wayang yang diidolakannya itu.

Dimas Surya muda mencintai Surti dan cintanya itu pun bersambut, bahkan keduanya telah bercinta. Namun, karena Dimas Surya dinilai belum siap, Surti justru memilih menikah dengan Hananto, atasan Dimas. Walau tampak menerima keadaan itu, cinta Dimas-Surti tidak pernah padam. Nama anak-anak Surti adalah pemberian Dimas (ketika masih berpacaran sudah merencanakannya). Ketika Dimas sudah menikah dengan Vivienne di Paris, walau disembunyikan, cintanya kepada Surti masih tetap menyala. Hal itu pula yang menyebabkan terjadinya perceraian antara keduanya. Dimas secara sadar menyamakan kisah cintanya dengan Bima, maka tokoh wayang itu kemudian diidolakannya. Bima tokoh wayang mencintai Drupadi, tetapi Drupadi justru lebih mencintai Arjuna, adiknya yang memang dikenal sebagai laki-laki paling tampan. Padahal, Bima yang paling menjaga harkat dan kehormatan Drupadi. Ketika Pandawa kalah bermain dadu dan Drupadi dipermalukan Kurawa (Drupadi diseret dan ditelanjangi oleh Dursasana), atau ketika Pandawa dihukum dan menyamar di Kerajaan Wirata (Drupadi dikejar-kejar Kencakarupa), Bima yang membela. Pengabdian Bima kepada Drupadi bahkan melebihi cinta Yudhistira kepada istrinya. Memang, pada akhirnya kelima Pandawa itu sama-sama menikahi Drupadi.

Aku sebetulnya lebih tertarik pada pilihan ayah. Sejak dulu dia selalu menyatakan dia tertarik pada Bima dan Ekalaya dalam Mahabharata.

Semula aku mengira ayah kagum karena Bima adalah perwakilan kelelakian. Tinggi, besar, dan protektif. Ternyata Ayah tertarik pada Bima karena kesetiaannya pada Drupadi, satu-satunya perempuan yang menjadi istri kakak beradik Pandawa. Pengabdian Bima pada Drupadi bahkan melebihi cinta Yudhistira pada istrinya. Adalah Bima yang membela harkat Drupadi yang dihina Kurawa saat kalah permainan judi. "Hanya Bima yang menjaga Drupadi ketika dia diganggu oleh banyak lelaki saat Pandawa dibuang ke hutan selama 12 tahun," kata Ayah menafsirkan dengan semangat. (Pulang, 2016:185).

Kisah Drupadi melakukan kawin secara poliandri terjadi pada cerita wayang versi India, sedang pada versi Jawa Drupadi hanya menjadi istri Yudhistira (Rajagopalachari, 2008; Sudjarwo dkk, 2010; Padmosoekotjo, 1992). Selain itu, pada cerita wayang versi Jawa tidak ada kisah Bima terlibat kisah cinta segitiga itu. Oleh karena itu, tampak bahwa kisah novel ini lebih berhipogram pada cerita wayang versi India atau sengaja didramatisasikan.

Kegagalan perkawinan Dimas SuryaVivienne terutama disebabkan Vivienne tidak dapat menerima kenyataan bahwa secara diam-diam Dimas Surya masih merindukan Surti. Apalagi di Indonesia Surti amat menderita sebagai mantan istri tahanan politik yang dibunuh. Dimas Surya tidak dapat pulang ke tanah air yang amat dirindukan karena tidak memiliki paspor dan sudah pasti akan ditangkap. Namun, ketika Lintang, anaknya, pergi Jakarta dan bertemu Alam, anak Surti, keduanya langsung jatuh cinta. Hal itu secara tidak langsung mempertemukan kembali Dimas Surya dan Surti Anandari lewat generasi kedua.Oleh karena itu, sebagaimana dikatakan Takwin (2012), percintaan kedua anak muda itu sekaligus dapat dipandang sebagai solusi kisah 
cinta kedua orang mereka yang tidak pernah kesampaian.

Selain menyamakan "nasib"-nya dengan Bima, Dimas Surya juga merasakan hal yang serupa dengan Ekalaya walau dengan alasan yang berbeda. Oleh pemerintah Orde Baru, Dimas Surya dan kawan-kawannya, Nugroho, Risjaf, dan Tjai dianggap sebagai terlibat walau secara tidak langsung dengan G30S/ PKI. Padahal, ketika terjadi periswa itu, mereka sedang bertugas di luar negri, dan sebenarnya kepergian Dimas Surya hanya sebagai pengganti. Paspor mereka dicabut dan mereka tidak berani pulang, maka tanpa dimauinya mereka menjadi eksil politik, menjadi orang-orang yang terbuang. Namun, rasa cinta tanah air mereka tidak pernah padam. Dimas mengekspresikan rasanya cintanya itu antara lain dengan mengoleksi batik bergambar wayang dan rupa-rupa rempahrempah dengan bau khas yang selalu mengingatkan Indonesia.

Tokoh wayang yang "bernasib" seperti itu, yaitu menjadi orang terbuang menurut Dimas Surya adalah Ekalaya. Ekalaya terbuang (atau dibuang) oleh Durna yang menolak menjadi gurunya karena telah memiliki murid Arjuna. Walau dibuang, Ekalaya tidak patah hati, maka kemudian ia membuat patung Durna untuk dijadikan "guru". Ternyata kemampuan Ekalaya justru dapat melebihi Arjuna, maka Durna meminta ibu jarinya sebagai konsekuensi guru-daksina 'persembahan murid kepada guru'. Ekalaya pun mematuhi permintaan gurunya itu. Dimas Surya yang terpaksa menjadi eksil itu menganggap secara metaforis bahwa dirinya "senasib" dengan Ekalaya. Jadi, sama halnya dengan kisah cinta segitiganya yang dimetaforakan lewat kisah cinta Bima, kisahnya sebagai eksil dimetaforakan seperti kisah Ekalaya.

Selain intensifnya transformasi cerita wayang, kesamaan lain antara novel Amba dan Pulang adalah pengangkatan tokoh Bhisma dan Dimas Surya yang sama-sama berstatus sebagai orang-orang yang "tidak bersih diri" dan atau "tidak bersih lingkungan". Bhisma tidak terlibat pemberontakan PKI, tetapi dituduh tersangkut, sebagai simpatisan, maka kemudian ditangkap ketika menghadiri acara peringatan kematiann kawannya, tanpa diadili, dan dibuang ke Pulau Buru. Dimas Surya juga bukan orang parti (PKI), bekerja di kantor berita, dikirim keluar negri hanya sebagai peserta pengganti konferensi internasional wartawan komunis, paspornya dicabut, dan akhirnya menjadi orang terbuang (eksil). Baik Bhisma maupun Dimas Surya adalah korban kekerasan oleh negara, oleh pemerintahan (Orde Baru) ketika itu karena tuduhan yang sebenarnya tidak benar (Ardana, 2013). Pada masa kekuasaan Orde Baru, siapa pun yang dinyatakan "tidak bersih diri" dan atau "tidak bersih lingkungan" dianggap (seolah-olah) sebagai common enemy (Meiseisar, 2015).

Tidak sedikit karya fiksi Indonesia yang mengambil setting peristiwa politik tahun 1965, sebuah peristiwa politik yang menggemparkan sejarah Indonesia. Pengangkatan latar politik tersebut selalu saja terlihat menarik, terlihat seksi, dengan cara dibuka sedikit demi sedikit sehingga pembaca menjadi penasaran (Ardana, 2013). Namun, paling tidak hal itu, sebagaimana dikatakan Amrzan Loebis (di halaman sampul), dapat dipandang sebagai bagian dari "perjuangan melawan lupa" akan luka sejarah bangsa ini yang tak kunjung pulih" $(A m b a)$ dan sebagai cara untuk merawat ingatan tentang salah satu "gempa politik" terbesar di negeri ini(Pulang). Atau, paling tidak dapat diharapkan generasi muda dewasa ini yang hanya mendengar peristiwa itu dari tulisan, termasuk dari fiksi, dapat mengingat dan mengambil pelajaran dari peristiwa politik itu. Sebagaimana dikatakan Takwin (2012) bahwa apa yang terjadi pada sekarang dapat menjadi stimulus bagi aktifnya ingatan 
tentang peristiwa pada masa lalu. Atau sebaliknya, apa yang diingatdari masa lalu dapat menjadi stimulus bagi konstruksi pikiran pada masa kini dan antisipasi masa depan.

Hubungan Kekeluargaan Tokoh. Perujukan pada cerita wayang juga terjadi dalam hal hubungan kekeluargaan tokoh cerita. Persoalan ini mungkin lebih tepat masuk dalam pembicaraan penokohan, namun sengaja dilakukan di sini karena mengandung unsur alur cerita. Hubungan kekeluargaan yang dimaksud adalah antara tokoh novel Amba serta Ambika dan Ambalika yang adalah kakak beradik. Hal itu jelas merupakan transformasi dari cerita wayang yang mengisahkan bahwa ketiga tokoh tersebut dengan nama yang sama adalah juga kakak beradik putri Raja Kasipura sebagaimana dikemukakan sebelumnya. Jadi, terdapat hubungan kekerabatan yang antara tokoh-tokoh cerita wayang dan tokoh-tokoh cerita novel. Hal itu semakin menegaskan adanya hubungan intertekstual antara novel Amba dan cerita wayang.

Pada cerita wayang, Ambika dan Ambalika kawin dengan Citrawirya, namun tidak berputra karena Citrawirya keburu gugur di medan tempur. Kedua putri tersebut kemudian dikawinkan dengan Abiyasa yang kemudian menurunkan Destharastra (ayah Kurawa) dan Pandu Dewanata (ayah Pandawa) yang kelak saling membunuh dalam Perang Besar Bharatayuda. Pada novel Amba, Ambika dan Ambalika tidak banyak dikisahkan. Ambika sedikit disebut karena dialah yang sering memberi tahu Amba perihal keadaan keluarga setelah Amba pergi ke Jakarta dan tidak pernah kembali ke kampungnya. Amba tokoh wayang meninggal sebelum kawin, tetapi Amba tokoh novel bahkan bercinta dengan Bhisma dan kemudian menghadirkan seorang putri, Srikandi. Srikandi tokoh wayang adalah putra Prabu Drupada dan tidak memiliki hubungan dengan Amba.
Pada novel Pulang adanya hubungan kekerabatan itu terjadi pada generasi kedua setelah Dimas Surya dan Surti. Tepatnya adalah anak kandung keduanya. Dimas Surya memetaforakan dirinya kepada Bima yang mencintai Drupadi, namun Drupadi justru mencintai Arjuna. Belakangan putra Bima, yaitu Gatotkaca, menikah dengan putra Arjuna, yaitu Pregiwa. Hal itu kemudian ditransformasikan dalam Pulang dengan mempertemukan anak Dimas Surya, yaitu Lintang, dengan Alam, anak Surti dengan Hananto, yang saling jatuh cinta pada pandangan pertama. Keduanya memang belum sempat (diceritakan) untuk menikah, namun percintaan serius sudah berlangsung. Padahal, Lintang masih ditunggu Narayana, kekasihnya di Paris. Jadi, kalaupun cinta kasih Dimas SuryaSurti tidak kesampaian, hal itu diteruskan oleh anak-anak mereka untuk "menyelesaikannya". Keadaan inilah yang oleh Takwin (2012) dikatakan sebagai solusi, sebuah solusi yang menarik.

Adanya transformasi dari cerita wayang secara intensif dalam kedua novel tersebut memperlihatkan bahwa dalam hal penciptaannya, kedua novel itu tidak dapat melepaskan diri dari konteks sosial budaya wayang yang masih kental di masyarakat Jawa dan bahkan Indonesia. Melihat sejarah hidupnya, kedua pengarang itu, Laksmi Pamuntjak dan Leila S. Chudori, tidak dibesarkan dalam lingkungan budaya masyarakat yang kental dengan cerita wayang. Namun, dengan membaca, memahami, menikmati, dan menghayati dengan intens keduanya mampu memasukkan cerita wayang ke dalam karyanya. Latar budaya wayang yang dihipogram diramu dengan tokoh yang bersangkutan dengan politik terlarang dalam jalinan cerita yang runtut dan menarik, kedua novel itu memiliki aspek penciptaan yang kuat, orisinal, dan dengan stile yang juga memikat. Hal yang demikian juga dikemukakan oleh Downes 
(2012) ketika mengkaji dan kemudian mengomentari tranformasi cerita wayang dalam beberapa novel Indonesia.

Secara umum dapat dikatakan bahwa cerita wayang yang dihipogram dalam kedua novel tersebut bersumber pada cerita, tokoh, dan karakter wayang yang baku, pakem, dan masih bersifat stereotip walau juga terlihat tidak hanya berhipogram pada cerita wayang versi Jawa, tetapi juga pada versi India. Hal itu berbeda misalnya, dengan hipogram tokoh dan cerita wayang Sinta dan Rahwana dalam novel Rahvayana, Aku Lala Padamu 1 (2014) dan Rahvayana, Aku Lala Padamu 2 (2015) karya SujiwoTejo. Pada kedua novel tokoh-tokoh wayang yang dimunculkan sebagai tokoh-tokoh yang campur aduk baik dari jatidiri antara tokoh wayang dan bukan wayang, karakter, profesi, latar, dan lain-lain. Kedua novel tersebut memperlihatkan adanya perkembangan wayang Jawa kontemporer yang banyak menyimpang dari pakem sebagaimana dikemukakan oleh Varela (2014).

Dilihat dari sisi pembaca, pembacaan dan pemahaman terhadap novel Amba dan Pulang, akan dapat dilakukan secara lebih penuh, bermakna, dan mengesankan, jika pembaca memahami cerita wayang. Ketika membaca kedua novel tersebut, pembaca yang memahami cerita wayang, secara sadar atau tidak sadar juga akan menghadirkan cerita wayang dalam pikir dan hatinya. Hal itulah antara lain yang dapat dipandang sebagai esensi hubungan intertekstual dalam pembacaan karya-karya yang saling berhubungan (Lesmater, 2012). Namun, pembaca yang tidak memahami cerita wayang juga masih dapat memahami dan menikmati kisah novel itu, tetapi tidak sepenuh dan semenjiwai sebagaimana halnya pembaca yang memahami cerita wayang.

\section{SIMPULAN}

Transformasi cerita wayang pada novel Amba dan Pulang secara intensif terli- hat pada dua unsur, (a) penokohan dan (b) alur. Pertama, transformasi penokohan mencakup tiga bentuk, yaitu hipogram nama dan karakter, karakter tanpa nama, dan nama tanpa karakter. Hipogram (sebagian) nama dan (sebagian) karakter tokoh wayang terlihat intensif pada tokoh Amba, Bhisma, dan Salwa (Amba), sedang hipogram karakter tokoh wayang tanpa nama terlihat pada Dimas Surya (Pulang). Di pihak lain, hipogram nama tokoh wayang tanpa disertai karakter ditemukan dalam banyak tokoh pada kedua novel itu, misalnya Ambika, Ambalika, dan Srikandi $(A m b a)$, serta Surti, Rukmini, Narayana, Bima, Andini, dan Rama $(P \mathcal{H}-$ lang). Adanya perujukan terhadap namanama dan karakter tokoh-tokoh wayang sekaligus menunjukkan bahwa cerita masih dijadikan rujukan budaya dalam penulisan novel Indonesia modern dewasa ini. Perujukan kepada tokoh-tokoh yang telah memiliki nama dan karakter yang baku dan stereotip akan menyebabkan penuturan menjadi lebih efisien dan komunikatif.

Kedua, transformasi alur paling tidakmencakup dua bentuk, yaitu kisah cinta segitiga dan hubungan kekeluargaan para tokoh. Alur kisah cinta segitiga dalam novel Amba melibatkan tokoh Amba, Salwa, dan Bhisma yang berhipogram pada cerita wayang dengan tokoh yang sama. Secara substansial kisah cinta segitiga dalam cerita tidak hampir sama dengan kisah pada novel, namun terjadi perbedaan latar, situasi, peristiwa, dan alasan terjadinya percintaan dan perpisahan. Pada cerita wayang, Amba dan Bhisma tidak bersentuhan sama sekali, tetapi pada kisah novel Amba bahkan hamil karena percintaannya dengan Bhisma walau tetap saja keduanya berpisah.

Di pihak lain, alur kisah cinta segitiga pada novel Pulang melibatkan tokoh Dimas Surya, Surti, dan Hananto lewat metafora kisah cinta Bima, Drupadi, dan Arjuna. Dalam wayang Bima mencintai 
Drupadi, tetapi Drupadi justru mencintai Arjuna, sedang dalam novel Dimas Surya mencintai Surti, tetapi Surti justru menikah dengan Hananto walau cinta keduanya tidak pernah padam. Keadaan itu berlanjut pada anak-anak keduanya, yaitu bahwa anak Dimas Surya, Lintang, saling mencintai dengan anak Surti, Alam, yang berhipogram pada perkawinan Gatotkaca (anak Bima) dengan Pergiwa (anak Arjuna). Hal itu selain menunjukkan adanya hubungan kekerabatan yang juga dihipogram dari cerita wayang, tampaknya dapat dipandang sebagai solusi kisah cinta kedua orang tua mereka yang tidak kesampaian.

Selain itu, kerinduan Dimas Surya pada tanah air yang sebagai eksil di luar negri berhipogram secara metaforis kepada Ekalaya. Ekalaya amat ingin berguru kepada Durna, tetapi ditolak sehingga ia eksis sebagai murid yang "terbuang". Kerinduan Dimas Surya pada tanah air diwujudkan dengan membuka rumah makan "Tanah Air", mengoleksi gambar tokoh-tokoh wayang, dan menyimpan rempah-rempah dengan bau khas Indonesia. Dimas Surya akhirnya dapat "pulang" ke tanah air setelah meninggal dan jasadnya dikuburkan di Karet. Jadi, kebebasan yang sangat diharapkan oleh para eksil itu, khususnya Dimas Surya, hanya dapat tercapai setelah mereka meninggal.

\section{UCAPAN TERIMA KASIH}

Ucapan terima kasih disampaikan kepada sejawat yang telah membantu, dalam bentuk apa pun, penelitian dan penulisan ini hingga wujudnya yang sekarang dalam bentuk artikel. Semoga keikhlasan kawan-kawan dijadikan Allah sebagai bernilai ibadah. Amin

\section{DAFTAR PUSTAKA}

Ardana, Alwi A. 2013. "Amba Ingin Pulang tapi Takut Jadi Komunis", IndoProgres. Online: http://indoprogress. com/2013/09/amba-ingin-pulang-tapitakut-jadi-komunis/.
Basuki, Ribut. 2006. Panakawan's Discourse of Power in Javanese Shadow Puppet during the New Order Regime: From Traditional Perspective to New Historicism. Kata, vol. 8, No. 1, pp: 68-88. Online: http://kata. petra.ac.id/index.php/ing/article/ viewFile/16472/16464.

Brown, Gilian \& George Yule. 1983. Discourse Analysis. Cambridge: Cambridge University Press.

Darma, Budi. 1995. Harmonium. Yogyakarta: Pustaka pelajar.

Downes, Meghan. 2012. Shadow on the Page: Javanese Wayang in Contemporary Indonesian Literarture. RIMA: Review of Indonesian and Malaysian Affairs, Vol 46 Issue 1. Online: http://connection.ebscohost.com/c/ articles/92582084/shadows-pagejavanese-wayang-contemporaryindonesian-literature.

Dwiyanto, Djoko, Sukatmi Susantika, Wiwien Widyawati. 2010. Ensiklopedi Wayang. Jogjakarta: Media Abadi.

Figueras-Lucero, Adelaida A. 1997. The Wayang Kulit the Narrative Framework of Pramudya Ananta Tur's Perburuan, Journal of English Studies and Comparative Literature, Vol. 2, No. 1, pp: 19-34. Online: http: //journals.upd.edu.ph/index.php/jescl/articlel download/2479/2345.

Habib, M.A.R. 2005. A History of Modern Literay Criticism, from Plato to Present. Malden, Oxford: Blackwell Publishing.

Kasnowihardjo, H. Gunadi . 2012. Wayang Purwa: within a Study of Archaeology, Art, and Identity of a Nation. Paper was presented for the International Seminar for Sharing Art Ocean Mountain, Samudraraksa Ship Museum, Candi Borobudur, Central Java, 27 April 2012.(http://www.academia. edu/3247508/ Wayang_Purwa_A_ Study_of_Archaeology_Art_and_Nation_Identity). 
Kuntowijoyo. 1984. “Penokohan dan Perwatakan dalam Sastra Indonesia", dalam Andy Zoeltom (ed). Budaya Sastra. Jakarta: Rajawali, pp. 127-136.

Kusmarwanti. 2010. “Wayang sebagai Refleksi Politik dalam Novel Mantra Pejinak Ular Karya Kuntowijoyo: Kajian Sosiologi Sastra dan Intertekstual". Tesis, UGM: Electronic Theses \& Dissertation (ETD). Online: http://etd.repository.ugm.ac.id/index. php?mod= penelitian_detail\&sub=Pe nelitianDetail\&act $=$ view\&typ $=\mathrm{html} \&$ buku_id $=47258$.

Lal, P. 1992. Mahabrata. Jakarta: Pustaka Jaya (PenerjemahHariadi S. Hartawardaya).

Lesmater, Tracy. 2012. What is "Intertextuality"? online: http://humanities. wisc.edu/assetsmisc/What_Is_Intertextuality.pdf

Meiseisar, Selvira. 2015. “Konstruksi Identitas Tahanan Politik Orde Baru dalam Novel Amba Karya Laksmi Pamuntjak", Commonline: Vol. 4 / No. 2 , pp 241-256. Online: http://journal.unair. ac.id/konstruksi-identitas-tahananpolitik-orde-baru-article-9363-media137-category-8.html.

Mustikasari, Diah; Andre Aldrin, \& Luluk Nuriyah. 2012. "Stories of Wayang Di Batas Angin by Yanusa Nugroho: Indonesia Wayang in Modern Literature". International Proceedings of Economics Development \& Research, Vol. 51, p17. Online:http://connection. ebscohost.com/c/articles/87742914/ stories-wayang-di-batas-angin-byyanusa-nugroho-indonesia-wayangmodern-literature.

Padmosoekotjo, S. 1992. Silsilah WayangPurwaMawa Carita, jilid I3/4VII, Surabaya: Citra Jaya Murti.

Rajagopalachari, C. 2008. Mahabharata, Yogyakarta: IRCiSod.

Sucipto, Mahendra. 2010. Ensiklopedi Tokoh-tokoh Wayang dan Silsilahnya. Yogyakarta: Narasi.

Sudjarwo, Heru S, Sumari, dan Undung Wiyono. 2010. Rupa \& Karakter Wayang Purwa. Jakarta: Kakilangit Kencana Prenada Media Group.

Sumukti, Tuti. 2006. Semar, Dunia Batin Orang Jawa. Yogyakarta: Galangpress.

Takwin, Bagus. 2012. "Novel Pulang, Menggugah Ingatan tentang Indonesia". Online: https://m.tempo.co/ $\mathrm{read} /$ news/2012/12/18/109449002/ novel-pulang-menggugah-ingatantentang-indonesia.

Varela, Miguel Escobar. 2014. WayangKontemporer: Innovations in Javanese Wayang. National University of Singapura: Dissertation. Online: http:// www.scholarbank. nus.edu.sg/bitstream/handle/10635/119799/Miguel Escobar2014.pdf?sequence $=1$.

Wibisono, Singgih. 2009. Wayang, Karya Agung Dunia. Online: http://www.Sastra-Indonesia.com/ 2009/12/Wayang, KaryaAgungDunia/. 